\title{
Descriptions of diplostomid metacercariae (Digenea: Diplostomidae) from freshwater fishes in the Tshwane area
}

\begin{tabular}{|c|c|}
\hline \multicolumn{2}{|c|}{$\begin{array}{l}\text { Authors: } \\
\text { Esmey B.E. Moema }{ }^{1} \\
\text { Pieter H. King } \\
\text { Johnny N. Rakgole } \\
\text { Chantélle Baker }^{3}\end{array}$} \\
\hline $\begin{array}{l}\text { Affiliations: } \\
{ }^{1} \text { Department } \\
\text { University of } \\
\text { Medunsa cam } \\
\text { South Africa }\end{array}$ & $\begin{array}{l}\text { of Biology, } \\
\text { impopo, } \\
\text { ipus, }\end{array}$ \\
\hline $\begin{array}{l}{ }^{2} \text { Department } \\
\text { University of } \\
\text { Medunsa cam } \\
\text { South Africa }\end{array}$ & $\begin{array}{l}\text { of Virology, } \\
\text { impopo, } \\
\text { pus, }\end{array}$ \\
\hline $\begin{array}{l}{ }^{3} \text { Electron Mic } \\
\text { University of } \\
\text { Medunsa cam } \\
\text { South Africa }\end{array}$ & $\begin{array}{l}\text { scope Unit, } \\
\text { mpopo, } \\
\text { us, }\end{array}$ \\
\hline $\begin{array}{l}\text { Corresponde } \\
\text { Esmey Moem }\end{array}$ & $\begin{array}{l}\text { lce to: } \\
\text { a }\end{array}$ \\
\hline $\begin{array}{l}\text { Email: } \\
\text { Esmey.Moem }\end{array}$ & a@ul.ac.za \\
\hline $\begin{array}{l}\text { Postal addres } \\
\text { PO Box 139, } \\
\text { South Africa }\end{array}$ & edunsa 0204, \\
\hline $\begin{array}{l}\text { Dates: } \\
\text { Received: } 22 \\
\text { Accepted: } 24 \\
\text { Published: } 25\end{array}$ & $\begin{array}{l}\text { Apr. } 2013 \\
\text { June } 2013 \\
\text { Sept. } 2013\end{array}$ \\
\hline $\begin{array}{l}\text { How to cite th } \\
\text { Moema, E.B.E } \\
\text { Rakgole, J.N. } \\
\text { 2013, 'Descrip } \\
\text { diplostomid n } \\
\text { (Digenea: Dip } \\
\text { from freshwa } \\
\text { in the Tshwan } \\
\text { Onderstepoor } \\
\text { Veterinary Re } \\
\text { Art. \#611, } 7 \text { p } \\
\text { http://dx.doi. } \\
\text { ojvr.v80i1.611 }\end{array}$ & $\begin{array}{l}\text { is article: } \\
\text {,, King, P.H., } \\
\text { \& Baker, C., } \\
\text { tions of } \\
\text { etacercariae } \\
\text { lostomidae) } \\
\text { ter fishes } \\
\text { e area', } \\
\text { t Journal of } \\
\text { search } 80(1) \text {, } \\
\text { ages. } \\
\text { org/10.4102/ }\end{array}$ \\
\hline $\begin{array}{l}\text { Copyright: } \\
\text { (C) 2013. The } \\
\text { Licensee: AOS } \\
\text { OpenJournals } \\
\text { is licensed un } \\
\text { Creative Com } \\
\text { Attribution Lic }\end{array}$ & $\begin{array}{l}\text { Authors. } \\
\text { IS } \\
\text { This work } \\
\text { der the } \\
\text { mons } \\
\text { cense. }\end{array}$ \\
\hline 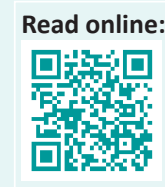 & $\begin{array}{l}\text { Scan this QR } \\
\text { code with your } \\
\text { smart phone or } \\
\text { mobile device } \\
\text { to read online. }\end{array}$ \\
\hline
\end{tabular}

Authors:

Affiliations:

${ }^{1}$ Department of Biology,

niversity of Limpopo,

Medunsa campus,

Medunsa campus,

University of Limpopo

Medunsa campus,

Correspondence to:

Esmey Moem

Email:

Postal address:

PO Box 139, Medunsa 0204,

Dates:

Received: 22 Apr. 2013

Accepted: 24 June 2013

How to cite this article:

Moema, E.B.E., King, P.H.,

Rakgole, J.N. \& Baker, C.,

2013, 'Descriptions of

from freshwater fishes

in the Tshwane area',

Onderstepoort Journal of

Art. \#611, 7 pages.

http://dx.doi.org/10.4102/

v80i1.611

Licensee: AOSIS

OpenJournals. This work

is licensed under the

Creative Commons

Read online:
The metacercarial (larval) stages of diplostomid digeneans are known to inhabit freshwater fish, causing tissue damage in the process. Due to their widespread diversity, little is known about their life cycle. The classification of these parasitic stages to the species level using only the morphology is very challenging due to the lack of genitalia; they are regarded to be the most important structures in the identification of these organisms. In this study, additional morphological information through light and scanning electron microscopy is given for two different diplostomids found in the cranial cavity of Clarias gariepinus and the vitreous chambers of Tilapia sparrmanii and Pseudocrenilabrus philander. The diplostomid metacercaria inhabiting the cranial cavity of Clarias gariepinus was morphologically identified as Diplostomulum (Tylodelphys) mashonense and an unknown metacercaria of the genus Diplostomum was found in the vitreous chambers of Pseudocrenilabrus philander and Tilapia sparrmanii. Both parasitic species' $28 \mathrm{~S}$ recombinant deoxyribonucleic acid genomic regions were successfully amplified using Dig 125/1500R primer pairs. The assay yielded a product of approximately 1300 base pairs as seen on the gel images. There were 14 nucleotide differences over the entire analysed sequences resulting in a $1.1 \%(14 / 1273)$ nucleotide difference. In line with the morphological characteristics of these parasites, there seemed to be a slight difference in their genetic makeup. The application of molecular techniques on digenetic trematodes seems very promising and may yield great potential in future descriptions of morphologically similar parasitic species.

\section{Introduction}

According to Gibson, Jones and Bray (2001), adult parasites of the family Diplostomidae are parasitic in many birds and mammals. Larval forms of this family use a variety of freshwater snails as first intermediate hosts and various fish species as second intermediate hosts.

Beverley-Burton (1963) from Zimbabwe and Niewiadomska $(1984,1986)$ from Poland pioneered early studies on the adults of the genus Diplostomum. Larval forms belonging to the genus Diplostomulum were also previously studied from the eyes and brain of freshwater fish from various parts of the world. These included the work done by: Pandey (1973) from India; Prudhoe and Hussey (1977), Chibwana et al. (2013) from Tanzania and Nigeria; Mashego and Saayman (1989) and Madanire-Moyo, Luus-Powell and Olivier (2010) from South Africa; Hendrickson (1978a, 1978b) and Höglund and Thulin (1992) from the Baltic Sea.

The aim of this research was to study the morphology and phylogeny of two diplostomid metacercariae; one from the eyes and the other from the cranial cavity of different freshwater fish species from two localities in the proximity of Tshwane, Gauteng Province, South Africa.

\section{Materials and methods}

Diplostomid metacercariae were collected through dissections of three freshwater fish species, namely Pseudocrenilabrus philander Weber, 1897, Tilapia sparrmanii A. Smith, 1840 and Clarias gariepinus Burchell, 1822 (C. gariepinus). They were collected from the Supersand Dam

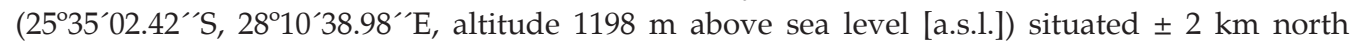
of the Bon Accord Dam in the Onderstepoort area, Gauteng and the Boekenhoutskloof farm Dam (253ㄴ $45.18^{\prime \prime} \mathrm{S}, 2^{\circ} 26^{\prime} 12.47^{\prime \prime} \mathrm{E}$, altitude $1214 \mathrm{~m}$, a.s.1.), approximately $15 \mathrm{~km}$ north of the Roodeplaat Dam Nature Reserve in the proximity of Tshwane, Gauteng Province, South Africa. Live forms of the metacercariae were studied using a compound microscope with the aid of vital stains. Specimens were fixed in $2.5 \%$ phosphate buffered glutaraldehyde $(\mathrm{pH}=7.2-7.4), 5 \%$ saline buffered solution and $70 \%$ ethanol respectively and stored until required. Standard techniques 
for light and scanning electron microscopy (SEM) were employed to study the internal and external ultrastructures of these parasites. Polymerase chain reaction (PCR) techniques were also performed pertaining to molecular structures on the same species.

\section{Light microscopy}

Specimens fixed in $70 \%$ ethanol were stained in haematoxylin or eosin and Van Cleave's haematoxylin staining solutions. Stained specimens were mounted on slides using DPX mounting medium. Projection drawings of mounted specimens were made by means of a drawing tube attached to a Nikon compound microscope (Nikon, Tokyo, Japan). For each description, a maximum of 20 specimens were drawn and measured, with all measurements given in micrometres $(\mu \mathrm{m})$. Morphological measurements are presented in the text as follows: minimum to maximum values, followed by the average value and standard deviation in parentheses. All light micrographs were taken using a Nikon Coolpix ${ }^{\circledR 990}$ digital camera fitted to the compound microscope.

\section{Scanning electron microscopy}

Specimens fixed in $2.5 \%$ gluteraldehyde were washed in Millonig's phosphate buffer $(\mathrm{pH}=7.2)$ and dehydrated through an graded series of ethanol (from $70 \%$ ethanol to $100 \%$ ethanol) for 30 seconds to one minute in each concentration. They were processed as follows: overnight critical point dried (Polaron, Watford, UK), mounted on aluminium stubs, sputter coated with gold (Emscope; Quorum Technologies, Ashford, UK) and examined using a Leica Stereoscan 420 SEM (Leica Electron Optics, UK).

\section{Polymerase Chain Reaction}

Specimens for PCR were suspended in 5\% saline buffered solution $(200 \mu \mathrm{L})$ and frozen in a $-70{ }^{\circ} \mathrm{C}$ freezer until required. During the extraction process, specimens were thawed and excess buffered saline solution (BSS: $800 \mathrm{~mL}$ distilled water, $8 \mathrm{~g} \mathrm{NaCl}, 0.2 \mathrm{~g} \mathrm{KCl}, 1.44 \mathrm{~g} \mathrm{Na}_{2} \mathrm{HPO}_{4}$ and $0.24 \mathrm{~g} \mathrm{KH}_{2} \mathrm{PO}_{4} ; \mathrm{pH}=7.4$ ) was removed. Deoxyribonucleic acids (DNA) were extracted using a QIAamp DNA mini kit (Qiagen, Valencia, CA, USA) following the manufacturer's instructions. Two parasite samples obtained from different locations, the brain and eyes of two fishes, were extracted in duplicates. In brief, specimens were transferred to $220 \mu \mathrm{L}$ lysis solution $(200 \mu \mathrm{L}$ ATL Buffer and $20 \mu \mathrm{L}$ Proteinase K) in microcentrifuge tubes. Samples were incubated at $56{ }^{\circ} \mathrm{C}$ for four hours followed by the addition of $200 \mu \mathrm{L}$ of absolute ethanol. The DNA in the lysate was allowed to bind to the spin columns and washed twice with the supplied buffers before being eluted in $200 \mu \mathrm{L}$ of elution buffer. The extracted DNA of parasites was stored at $-20{ }^{\circ} \mathrm{C}$ until analysis. The $28 \mathrm{~S}$ rDNA was amplified using the primers DIG12 (5-AAGCATATCACTAAGCGG-3) and 1500R (5-GCTATCCTGAGGGAAACTTCG-3) (Tkach et al. 1999; Tkach, Pawloski \& Mariaux 2000). The PCR reaction was performed in a final volume of $25 \mu \mathrm{L}$. The reagents at a final concentration of $0.2 \mathrm{mM}$ for dNTPs, $1.5 \mathrm{mM} \mathrm{MgCl}{ }_{2}$
$0.2 \mu \mathrm{M}$ each of primers and $1 \mathrm{U}$ per reaction of Taq polymerase (Bioline, BioTaq, London, UK) were used. The PCR products were sequenced on the $\mathrm{ABI} 3100 \mathrm{XL}$ sequencing platform (Life Technologies, Foster City, CA, USA). The sequences were edited using ChromasPro v1.5 (Technelysium Pty, Ltd, Queensland, Australia). Additional sequences were downloaded from GenBank (accession numbers are shown on the phylogenetic tree in the results section) and aligned using ClustalW within BioEdit (Hall 1999). The phylogenetic trees were constructed using MEGA v5.22 (Tamura et al. 2011).

This research project met the requirements of the Medunsa Research Ethics Committee (BP 05/2005) and the Animal Ethics Committee (AEC 02/05) of the University of Limpopo, South Africa. Fish species that were collected were kept under controlled laboratory conditions with sufficient light, air and food according to acceptable standards. They were anaesthetised using clove oil prior to dissection.

\section{Results}

Metacercaria: Diplostomid metacercaria A [Diplostomulum (Tylodelphys) mashonense] (Figure 1a).

The host is Clarias gariepinus sampled from the Boekenhoutskloof farm Dam in the Gauteng Province and its preferred site in the host is the brain cavity.

The metacercariae were found unencysted in the cranial cavity of the sharptooth catfish, C. gariepinus. A few were collected around the frontal lobe, however, the majority of these larval stages had migrated posteriorly into the cavity. The numbers varied from a minimum of eight to over a

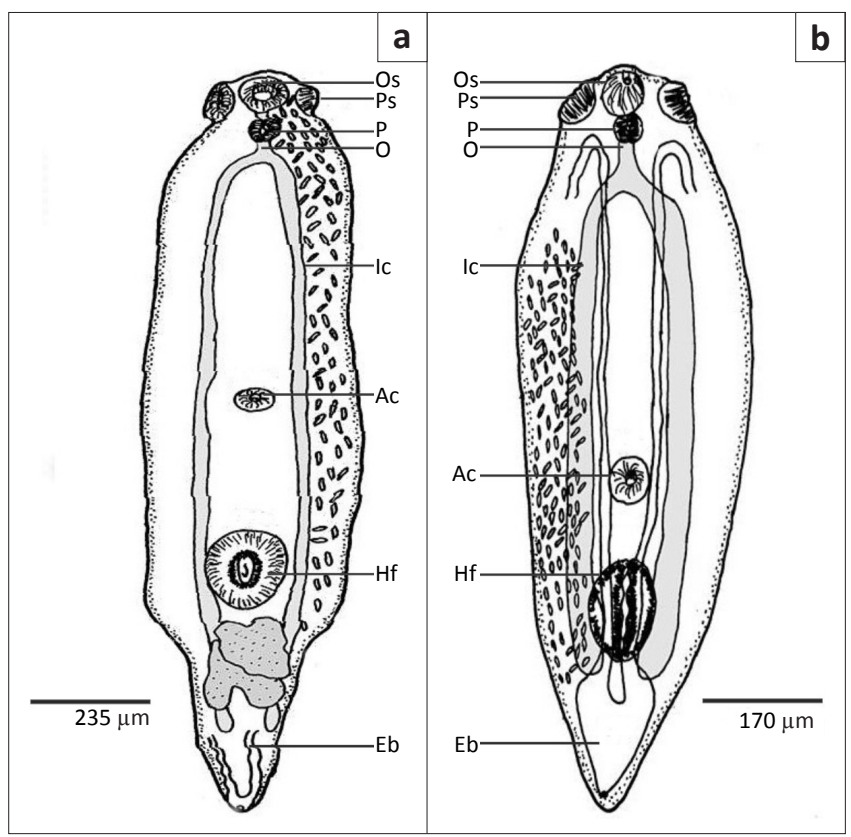

Ac, Acetabulum; Eb, Excretory bladder; O, Oeophagus; Hf, Holdfast organ; Ic, Intestinal caeca; Os, Oral sucker; P, Pharynx; Ps, Pseudosuckers.

FIGURE 1: Light microscope projection drawings, (a) Diplostomid metacercaria A [Diplostomulum (Tylodelphys) mashonense] from the cranial cavity of Clarias gariepinus collected from Boekenhoutskloof farm dam and (b) Diplostomid metacercaria B from the vitreous chamber of Tilapia sparrmanii and Pseudocrenilabrus philander collected from Supersand dam, Gauteng Province. 
hundred specimens per fish host. The metacercaria appeared to be off-white and elongated (Figure 1a; Figures 2a and 2b). The foliate body measured $946 \mu \mathrm{m}-1917 \mu \mathrm{m}(1409 \mu \mathrm{m} \pm$ $302 \mu \mathrm{m})$ long x $240 \mu \mathrm{m}-485 \mu \mathrm{m}(375 \mu \mathrm{m} \pm 75 \mu \mathrm{m})$ wide.

The body was comprised of a long and distinct forebody, followed by a small hindbody. It had an oral sucker (Figure 2c), which was situated at the anterior end of the body. It measured $36 \mu \mathrm{m}-90 \mu \mathrm{m}(70 \mu \mathrm{m} \pm 17 \mu \mathrm{m}) \times 42 \mu \mathrm{m}-96 \mu \mathrm{m}$ $(72 \mu \mathrm{m} \pm 14 \mu \mathrm{m})$. The tegument around the oral sucker was surrounded by non-ciliated serrated receptors (Figure 2c). Bordering the oral sucker were two pseudosuckers (Figure 1a), $54 \mu \mathrm{m}-120 \mu \mathrm{m}(73 \mu \mathrm{m} \pm 22 \mu \mathrm{m}) \times 24 \mu \mathrm{m}-84 \mu \mathrm{m}$ $(48 \mu \mathrm{m} \pm 16 \mu \mathrm{m})$, which were situated bilaterally at the anterior end of the body. The oral sucker (Figure 2c) continued into a muscular pharynx measuring $24 \mu \mathrm{m}-60 \mu \mathrm{m}$ $(46 \mu \mathrm{m} \pm 13 \mu \mathrm{m}) \times 30 \mu \mathrm{m}-60 \mu \mathrm{m}(47 \mu \mathrm{m} \pm 10 \mu \mathrm{m})$. A short oesophagus measuring $30 \mu \mathrm{m}-108 \mu \mathrm{m}(40 \mu \mathrm{m} \pm 27 \mu \mathrm{m})$ x $12 \mu \mathrm{m}-24 \mu \mathrm{m}(19 \mu \mathrm{m} \pm 4 \mu \mathrm{m})$ bifurcated into two long intestinal caeca, $772 \mu \mathrm{m}-1371 \mu \mathrm{m}(1111 \mu \mathrm{m} \pm 247 \mu \mathrm{m})$ $\mathrm{x} 18 \mu \mathrm{m}-36 \mu \mathrm{m}(28 \mu \mathrm{m} \pm 7 \mu \mathrm{m})$, within the hindbody at the posterior end of the body.

A spherical acetabulum that was similar in size to the oral sucker (Figure 2d), was situated midventrally on the body and measured $36 \mu \mathrm{m}-90 \mu \mathrm{m}(71 \mu \mathrm{m} \pm 17 \mu \mathrm{m}) \times 30 \mu \mathrm{m}-96 \mu \mathrm{m}$ $(67 \mu \mathrm{m} \pm 21 \mu \mathrm{m})$. The tegument around the acetabulum wall (Figure 2d) had no sensory receptors, but had ridges that were equally distributed around it. An oval-shaped holdfast organ (Figure 2e) with a deep fissure measured $156 \mu \mathrm{m}$ $198 \mu \mathrm{m}(180 \mu \mathrm{m} \pm 15 \mu \mathrm{m}) \times 24 \mu \mathrm{m}-150 \mu \mathrm{m}(101 \mu \mathrm{m} \pm 48 \mu \mathrm{m})$ and was situated between the acetabulum and the posterior end of the body. Genital primodia, consisting of two testes, occurred anteriorly in the hindbody. The anterior testis was asymmetrical, measuring $102 \mu \mathrm{m}-467 \mu \mathrm{m}(199 \mu \mathrm{m} \pm 120 \mu \mathrm{m})$ $\mathrm{x} 114 \mu \mathrm{m}-263 \mu \mathrm{m}(179 \mu \mathrm{m} \pm 50 \mu \mathrm{m})$, and lay in line with the junction of the forebody and the hindbody. It was also placed more to the right in the hindbody. The posterior testis on the other hand was bilobed and measured $96 \mu \mathrm{m}-155 \mu \mathrm{m}(126 \mu \mathrm{m}$ $\pm 27 \mu \mathrm{m}) \times 138 \mu \mathrm{m}-221 \mu \mathrm{m}(176 \mu \mathrm{m} \pm 24 \mu \mathrm{m})$ (Figure 1a).

The excretory system was not observed due to the copious amount of calcareous bodies found in the body. The anterior body tegument was relatively smooth in the area around the oral sucker (Figure 2f), but became unevenly ridged posteriorly (Figure $2 \mathrm{~g}$ ) with non-ciliated papillae all over the body surface (Figure $2 b-h$ ). There were no spines on the body tegument.

Metacercaria: Diplostomid metacercaria B (Figure 1b).

The hosts are Tilapia sparrmanii and Pseudocrenilabrus philander sampled from the Supersand Dam in the Gauteng Province and its preferred site in the host is the vitreous chamber.

These metacercariae were found unencysted in the vitreous chamber of small southern mouth-brooders ( $P$. philander) and banded tilapian (T. sparrmanii) species. The number of specimens varied from a minimum of two to a maximum of 12 per fish host. The metacercaria (Figure 1b; Figures
$3 a$ and $3 b$ ) was whitish in colour with an elongated body. The spatulate body measured $832 \mu \mathrm{m}-1263 \mu \mathrm{m}(1019 \mu \mathrm{m} \pm$ $138 \mu \mathrm{m})$ long $\times 257 \mu \mathrm{m}-407 \mu \mathrm{m}(340 \mu \mathrm{m} \pm 50 \mu \mathrm{m})$ wide.

The body was comprised of a well-developed oral sucker (Figure 3c), which measured $42 \mu \mathrm{m}-72 \mu \mathrm{m}(55 \mu \mathrm{m} \pm 9 \mu \mathrm{m})$ x $30 \mu \mathrm{m}-60 \mu \mathrm{m}(51 \mu \mathrm{m} \pm 10 \mu \mathrm{m})$. This sucker was located subterminally at the anterior end of the body and the tegument around it was not armed with receptors. Welldeveloped pseudosuckers (Figure $1 \mathrm{~b}$ and Figure 3a) measuring $24 \mu \mathrm{m}-42 \mu \mathrm{m}(34 \mu \mathrm{m} \pm 6 \mu \mathrm{m}) \times 36 \mu \mathrm{m}-84 \mu \mathrm{m}$ $(59 \mu \mathrm{m} \pm 15 \mu \mathrm{m})$ flanked the oral sucker.

The mouth that was located in the oral sucker connected to a muscular pharynx measuring $30 \mu \mathrm{m}-54 \mu \mathrm{m}(43 \mu \mathrm{m} \pm$ $8 \mu \mathrm{m}) \times 30 \mu \mathrm{m}-54 \mu \mathrm{m}(43 \mu \mathrm{m} \pm 6 \mu \mathrm{m})$. The pharynx lead to a very short oesophagus that measured $24 \mu \mathrm{m}-84 \mu \mathrm{m}(39 \mu \mathrm{m} \pm$ $18 \mu \mathrm{m}) \times 18 \mu \mathrm{m}-24 \mu \mathrm{m}(19 \mu \mathrm{m} \pm 2 \mu \mathrm{m})$. The oesophagus then bifurcated into two long intestinal caeca, $557 \mu \mathrm{m}-988 \mu \mathrm{m}$ $(717 \mu \mathrm{m} \pm 141 \mu \mathrm{m}) \times 18 \mu \mathrm{m}-42 \mu \mathrm{m}(29 \mu \mathrm{m} \pm 7 \mu \mathrm{m})$, ending at the posterior end of the holdfast organ. A spherical acetabulum (Figure 3d) measuring $30 \mu \mathrm{m}-66 \mu \mathrm{m}(51 \mu \mathrm{m} \pm 12 \mu \mathrm{m})$ in diameter was situated along two-thirds of the body length. It was somewhat smaller than the oral sucker.

An elliptical holdfast organ (Figure 3e) with hymen measured $96 \mu \mathrm{m}-180 \mu \mathrm{m}(131 \mu \mathrm{m} \pm 29 \mu \mathrm{m}) \times 42 \mu \mathrm{m}-96 \mu \mathrm{m}(68 \mu \mathrm{m} \pm$ $18 \mu \mathrm{m})$ and was situated at the posterior end of the forebody. A conspicuous V-shaped excretory bladder (Figure $1 \mathrm{~b}$ and Figure 3a) measuring $138 \mu \mathrm{m}-240 \mu \mathrm{m}(172 \mu \mathrm{m} \pm 32 \mu \mathrm{m})$ x $72 \mu \mathrm{m}-132 \mu \mathrm{m}(98 \mu \mathrm{m} \pm 21 \mu \mathrm{m})$ was situated at the posterior end of the hindbody. No flame cells were observed due to the rod-shaped calcareous bodies in the body. The genital primodia were also not observed, most probably due to the developmental stage of the parasites that were examined. An excretory pore was present at the posterior end of the hindbody (Figure 3h).

The non-ciliated receptors were observed posterior to the oral sucker (Figure 3f) surrounding the acetabulum (Figure 3d) and in most of the body tegument (Figures $3 \mathrm{~g}$ and $3 \mathrm{~h}$ ).

\section{Polymerase Chain Reaction}

Parasite samples were successfully amplified using the Dig 125/1500R primer pairs. Three of the extracts tested positive: two from the brain and one from the eye. The assay yielded a product of about 1300 base pairs (bp) as seen on the gel images. Brain sample sequences were $100 \%$ similar. The sequence of eye sample differed from the one obtained from the brain by having one base pair longer in the sequenced region. In addition, there were 14 nucleotide differences over the entire analysed sequences resulting in a $1.1 \%(14 / 1273)$ nucleotide difference. Table 1 shows the specific locations of the base differences. The sequences were submitted to Genbank under the following accession numbers: KF189071 (brain) and KF189072 (eye).

Nucleotide positions were only based on the analysed regions of the two sequences. A phylogenetic tree (Figure 4) was constructed using the two sample sequences along with 

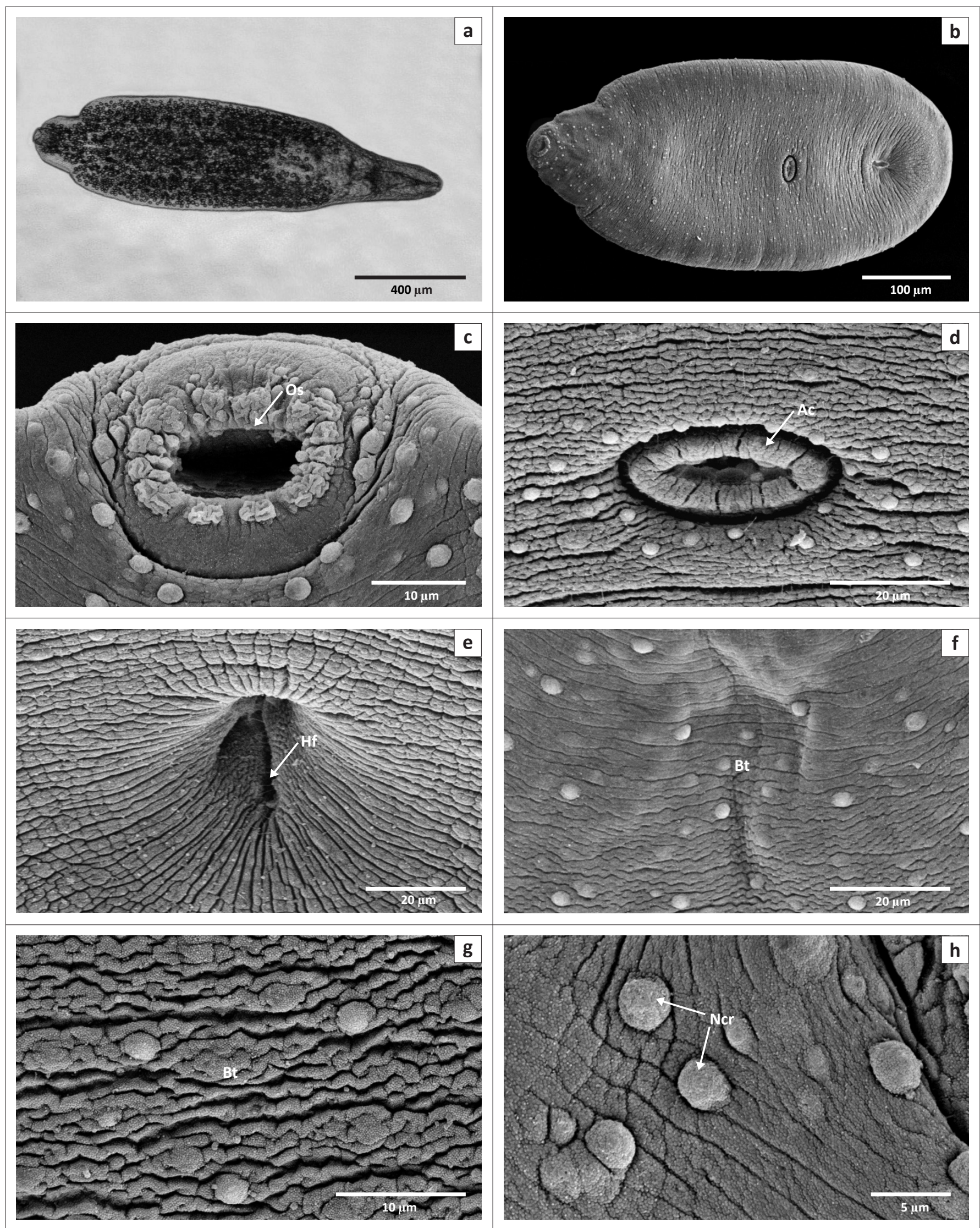

Note: Figure $\mathrm{b}-\mathrm{h}$ are scanning electron micrographs of Diplostomid metacercaria A [Diplostomulum (Tylodelphys) mashonense] from the cranial cavity of Clarias gariepinus collected from Boekenhoutskloof farm dam, Gauteng Province. Host: Clarias gariepinus. Preferred site in the host: brain cavity. Locality: Boekenhoutskloof farm Dam, Gauteng Province

Os, Oral sucker; Ac, Acetabulum; Hf, Holdfast organ; Bt, body tegument; Ncr, Non-ciliated receptors

FIGURE 2: Light and scanning electron micrograph, (a) Light micrograph, (b) Whole mount, (c) Oral sucker, (d) Acetabulum, (e) Holdfast organ, (f) Anterior body tegument, (g) Body tegument at the acetabular region and (h) Non-ciliated receptors on body tegument. 

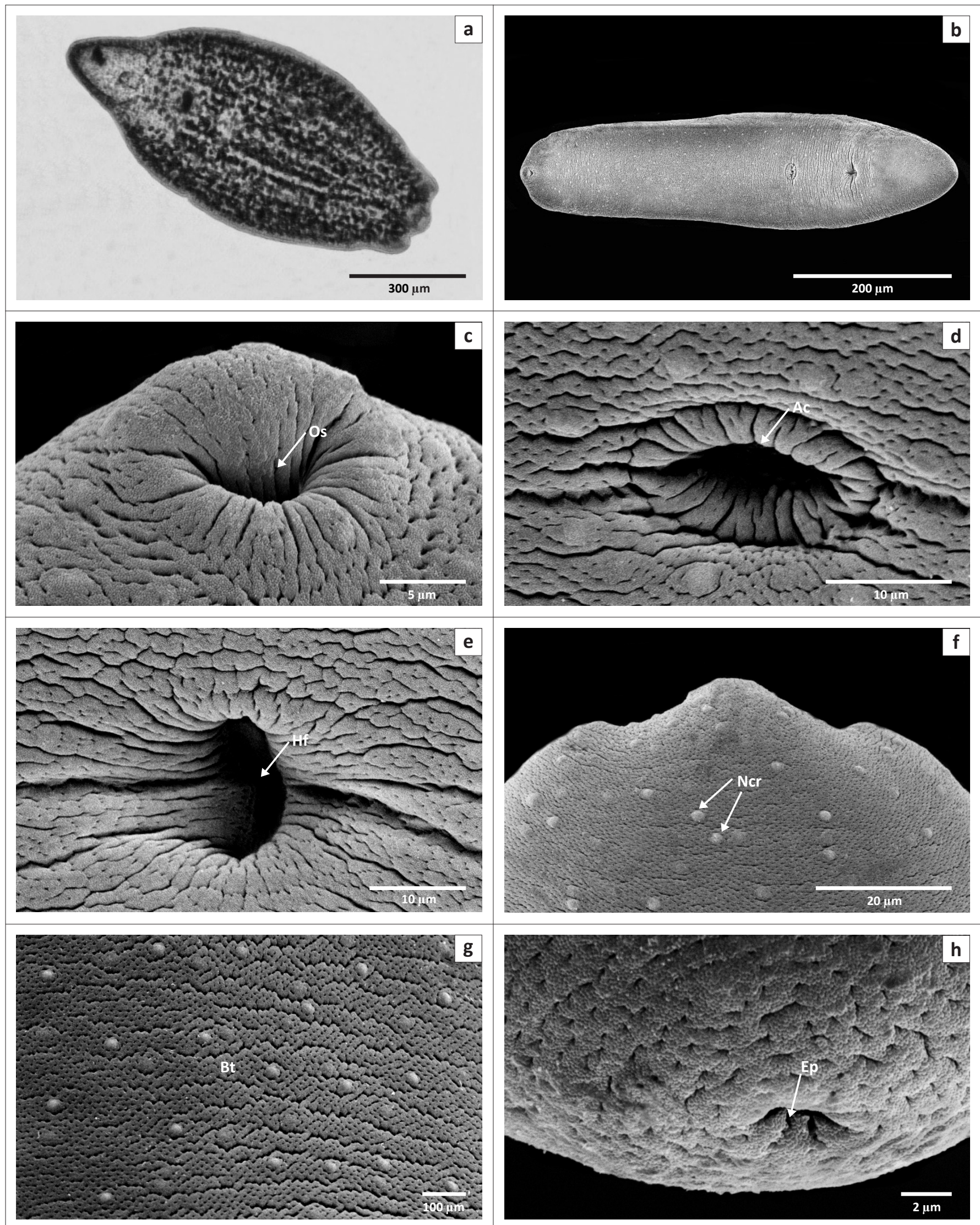

Note: Figure $\mathrm{b}-\mathrm{h}$ are scanning electron micrographs of Diplostomid metacercaria B from the vitreous chamber of Tilapia sparrmanii and Pseudocrenilabrus philander collected from Supersand dam, Gauteng Province. Hosts: Tilapia sparrmanii (T. sparrmanii) and Pseudocrenilabrus philander (P. philander). Preferred site in the host: Vitreous chamber. Locality: Boekenhoutskloof farm Dam and Supersand Dam, Gauteng Province

Os, Oral sucker; Ac, Acetabulum; Hf, Holdfast organ; Ncr, Non-ciliated receptors; Bt, Body tegument; Ep, Excretory pore

FIGURE 3: Light and scanning electron micrographs, (a) Light micrograph, (b) Whole mount, (c) Oral sucker, (d) Acetabulum, (e) Holdfast organ, (f) Non-ciliated receptors dorso-anteriorly on the body, (g) Body tegument with many Non-ciliated receptors and (h) Excretory pore. 
TABLE 1: Differences in the nucleotides across the genomes of two diplostomid metacercariae from the eyes of Tilapia sparrmanii and Pseudocrenilabrus philander, and the brain cavity of Clarias gariepinus.

\begin{tabular}{|c|c|c|c|c|c|c|c|c|c|c|c|c|c|c|}
\hline Nucleotides & 8 & 136 & 239 & 479 & 482 & 607 & 631 & 635 & 672 & 687 & 756 & 787 & 836 & 1144 \\
\hline Brain & G & A & C & A & A & C & C & G & A & $\mathrm{T}$ & A & - & $T$ & C \\
\hline Eye & $\mathrm{T}$ & G & $\mathrm{T}$ & G & G & $\mathrm{T}$ & $\mathrm{T}$ & A & G & C & G & $\mathrm{T}$ & C & G \\
\hline
\end{tabular}

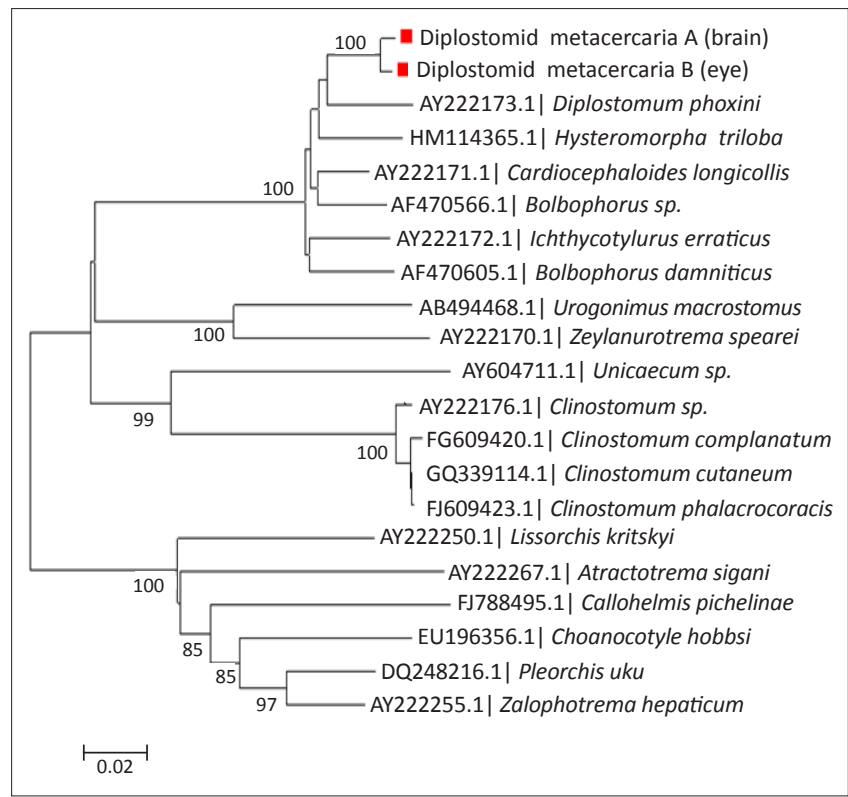

FIGURE 4: A phylogenetic tree showing the brain and eye diplostomids in relation to other parasites from the GenBank database.

the similar sequences downloaded during a Basic Local Alignment Search Tool (BLAST) analysis from the Genbank database.

\section{Discussion}

In this study, two dissimilar diplostomids were found to infect three fish species. Diplostomid metacercaria A was only found in the cranial cavity of C. gariepinus, whereas diplostomid metacercaria B was only found in the vitreous chamber of T. sparrmanii and P. philander. From this study it is evident that the two diplostomids are host specific and site specific due to the niches where they were sampled.

Both the cranial cavity and the eye diplostomid metacercariae were found unencysted at their respective sites. They were found to be moving freely in the cerebrospinal fluid in the region of the frontal lobes and vitreous humour of the eye, respectively.

Eight catfish that were dissected and examined in the present study were infected with the larvae in their cranial cavity. However, they did not show any signs of distress caused by these parasites. Khalil (1963) described Diplostomum tregenna, Nazmi Gohar, 1932 from the cranial nerves of Clarias lazera from the River Nile. He observed three stages of this parasite; the third stage was well-developed showing genitalia. Beverley-Burton (1963) described an adult diplostomula of Diplostomulum (Tylodelphys) mashonense (D. [T.] mashonense); the metacercariae were discovered in the cranial cavity of Clarias mossambicus, which was synonymous to C. gariepinus in Southern Rhodesia (now known as Zimbabwe).
Similarly, Mashego and Saayman (1989) described D. (T.) mashonense collected from C. gariepinus from dams around the Limpopo Province (formerly known as Lebowa). The latter authors' observations were that the metacercariae concentrated more on the frontal lobes of the brain in young hosts and thereafter they were found to have moved posteriorly as the hosts aged. This phenomenon was also observed during the present research study. These larvae were found to be very similar to the one described by the abovementioned authors and further, it was also very difficult to observe the excretory system including the flame cells. The metacercariae found in the cranial cavity of $C$. gariepinus during our investigation can therefore be identified as the larval stage of $D$. (T.) mashonense.

Tilapia sparrmanii specimens were found to be more frequently infected by eye diplostomid metacercariae than $P$. philander. It is still unclear as to why this should be the case, but immunity and the daily activities of the fish species may possibly have an influence. Hendrickson (1978a, 1978b) made observations about the eye diplostomids Diplostomum scheuringi, Hughes, 1929 and Diplostomum spathaceum respectively that were sampled from Wyoming fish. However, in his study observations were that some fish species were less infected than others and that these parasites had little, if any, effect on the sight of the fish.

Pandey (1973) described another type of eye diplostomid, Diplostomulum opthalmi (Pandey 1970), from freshwater fish in India. The eye diplostomid metacercaria observed in the present study is very similar to the one described by Hendrickson (1978a, 1978b) and Pandey (1973). However, it differs in the body tegument and size, has suckers that are spined and there is an absence of pseudosuckers. In order to classify this diplostomid species as a new species, the adult stage of this larval parasite will have to be found or experimentally raised. Only then would the taxonomic status of this species be able to be commented on.

Although the diplostomid metacercariae in the present study seem morphologically similar to the metacercariae described by other researchers, morphological studies are simply not sufficient. The morphology of organisms may undergo micro-evolutionary adaptation over time as the environment changes due to many external factors. Factors like $\mathrm{pH}$, temperature, nutrients, light, health, age, as well as angles of observation may introduce variation of the same organism and are therefore very subjective even with standardised guidelines (Huyse, Poulin \& Théron 2005). Phylogenetic studies were thus conducted on these metacercarial stages.

In line with the morphological characteristics of the two parasites, there seemed to be a slight difference in their 
genetic make-up. From the 1273 bp of a $28 \mathrm{~S}$ region, a $1.03 \%$ difference exists at DNA level. This is thought to be a highly conserved region for most organisms and should therefore be common to organisms of the same species. Lower homology values will be expected for non-conserved regions of these organisms, such that their full length sequences could differ by as much as $15 \%$. The power of phylogenetic analysis is undermined by the lack of parasite sequences in the Genbank database and therefore renders a limitation into complete characterisation of these organisms. The phylogenetic tree thus constructed, clusters the parasites in the present study with those that belong to the Superfamily Diplostomoidea and can unfortunately only resolve the samples studied to the Order Strigeidida. There are mixed families within the same node when analysing this phylogenetic tree to the family level.

This is the first study to report on the larger fragment of the 28S rDNA of diplostomids from the cranial cavity of C. gariepinus and the eyes of P. philander and T. sparrmanii. Presently there are no related sequences in the GenBank database. However, there is a recent report on phylogenetic studies of diplostomids collected from the brain of $C$. gariepinus sampled from Nigeria and Tanzania, of which the sequences covered up to the ITS- 2 region (Chibwana et al. 2013). Unfortunately the sequences of the present study cannot be compared to those generated in the previous work due to the fact that they both target exclusive DNA regions. The only sequence that links to the sequences from our study (and that of Chibwana et al. 2013) is Alaria alata (accession number JF820609). Since there are no related sequences in the database, we can only base our nomenclature on the morphology.

This was a pilot study from the Department of Biology, which aimed to assess the possibility of applying molecular biology techniques to the investigation of larval digenetic parasites. The application of molecular techniques on digenetic trematodes seems very promising and may yield great potential in future descriptions of these parasitic species.

\section{Recommendations}

We recommend a full length genome analysis of these two organisms in order to establish more definitive evidence of whether they belong to the same species. Further than that, archived specimens that have been described using biological and morphological characteristics should be genetically analysed in order to increase the information in the database of these organisms in GenBank.

\section{Acknowledgements}

SEM equipment utilised during this investigation was supported by the Department of Science and Technology in partnership with the National Research Foundation of South Africa. The Department of Virology, Medunsa campus allowed us to utilise their PCR laboratories for molecular work.

\section{Competing interests}

The authors declare that they have no financial or personal relationship(s) that may have inappropriately influenced them in writing this article.

\section{Authors' contributions}

E.B.E.M. (University of Limpopo) was the principal investigator and this study forms part of her doctoral thesis. P.H.K. (University of Limpopo) was the postgraduate supervisor of this study. C.B. (University of Limpopo) was a co-worker involved with all aspects of micrography and technical finishing of photographic plates. J.N.R. (University of Limpopo) was involved in the phylogenetic studies of the present study.

\section{References}

Beverley-Burton, M.M., 1963, 'A new strigeid, Diplostomum (Tylodelphys) mashonense n. sp., (Trematoda: Diplostomidae), from the Grey Heron, Ardea cinerea L. in southern Rhodesia, with an experimental demonstration of part of the life cycle', Revue de Zoologie et de Botanique Africaines LXVII, 291-308.

Chibwana, F.D., Blasco-Costa, I., Georgiva, S., Hosea, K.M., Nkwengulila, G., Scholz, T. \& Kostadinova, A., 2013, 'A first insight into the barcodes for African diplostomids (Digenea: Diplostomatidae): Brain parasites in Clarias gariepinus (Siluriformes: Clariidae)', Infection, Genetics and Evolution 17, 62-70. http:// dx.doi.org/10.1016/j.meegid.2013.03.037, PMid:23542455

Gibson, D.I., Jones, A. \& Bray, R.A., 2001, 'Keys to the Trematoda, vol. 1', CABI Publishing, London.

Hall, T.A., 1999, 'BioEdit: A user-friendly biological sequence alignment editor and analysis program for Windows 95/98/NT', Nucleic Acids Symposium Series 41, 95-98.

Hendrickson, G.L., 1978a, 'Observations on Strigeoid trematodes from the eyes of Southeastern Wyoming fish. I. Diplostomulum spathaceum (Rudolphi, 1819)', Proceedings of the Helminthological Society 45, 60-64.

Hendrickson, G.L., 1978b, 'Observations on Strigeoid trematodes from the eyes of Southeastern Wyoming fish. II. Diplostomulum scheuringi Hughes, 1929, Neascus ptychocheilus (Faust, 1917), and other types', Proceedings of the Helminthological Society 45, 64-68.

Höglund, J. \& Thulin, J., 1992, 'Identification of Diplostomum spp. in the retina of perch Perca fluviatilis and the lens of roach Rutilus rutilus from the Baltic Sea - an experimental study', Systematic Parasitology 21, 1-19.

Huyse, T., Poulin, R. \& Théron, A., 2005, 'Speciation in parasites: A population genetics approach', Trends in Parasitology 21(10), 469-475. http://dx.doi.org/10.1016/j. pt.2005.08.009, PMid:16112615

Khalil, L.F., 1963, 'On Diplostomulum tregenna, the diplostomulum stage of Diplostomum tregenna Nazmi Gohar, 1932 with an experimental demonstration of part of the life cycle', Journal of Helminthology 37(3), 199-206. http://dx.doi. org/10.1017/S0022149X00003783

Madanire-Moyo, G.N., Luus-Powell, W.J. \& Olivier, P.A.S., 2010, 'Ecology of metazoan parasites of Clarias gariepinus (Osteicthyes: Clariidae) from the NwanediLuphephe Dams of the Limpopo River system, South Africa' African Zoology 45(2), 233-243. http://dx.doi.org/10.3377/004.045.0202

Mashego, S.N. \& Saayman, J.E., 1989, 'Digenean trematodes and cestodes of Clarias gariepinus (Burchell, 1822) in Lebowa, South Africa, with taxonomic notes', South African Journal of Wildlife Research 19, 17-20.

Niewiadomska, K., 1984, 'Present status of Diplostomum spathaceum (Rudolphi, 1819) and differentiation of Diplostomum pseudospathaceum nom. nov (Trematoda: Diplostomidae)', Systematic Parasitology 6, 81-86. http://dx.doi. org/10.1007/BF02185515

Niewiadomska, K., 1986, 'Verification of the life-cycles of Diplostomum spathaceum (Rudolphi, 1819) and D. pseudospathaceum Niewiadomska, 1984 (Trematoda: Diplostomidae)', Systematic Parasitology 8, 23-31.

Pandey, K.C., 1973, 'Studies on metacercariae of freshwater fishes of India. II. Description of a known and five unknown strigeid metacercariae from Lucknow', Journal of Indian Zootomy 14(3), 155-166.

Prudhoe, S. \& Hussey, C.G., 1977, 'Some parasitic worms in fresh-water fishes and fish predators from the Transvaal, South Africa', African Zoology 12, 113-148.

Tamura, K., Peterson, D., Peterson, N., Stecher, G., Nei, M. \& Kumar, S., 2011, 'MEGA5 Molecular evolutionary genetics analysis using maximum likelihood, evolutionary distance, and maximum parsimony methods', Molecular Biology and Evolution 28(10), 2731-2739. http://dx.doi.org/10.1093/molbev/msr121, PMid:21546353, PMCid:PMC3203626

Tkach, V., Grabda-Kazubska, B., Pawlowski, J. \& Swiderski, Z., 1999, 'Molecular and morphological evidences for close phylogenetic affinities of the genera Macrodera, Leptophallus, Metaleptophallus and Paralepodema (Digenea: Plagiorchidea)', Acta Parasitologica 44, 170-179.

Tkach, V., Pawlowski, J. \& Mariaux, J., 2000, 'Phylogenetic Analysis of the suborder Plagiorchiata (Platyhelminthes: Digenea) based on partial IsrDNA sequences', International Journal of Parasitology 30, 83-93. http://dx.doi.org/10.1016/ S0020-7519(99)00163-0 